\title{
Enhanced Bioconversion of Cellobiose by Industrial Saccharomyces cerevisiae Used for Cellulose Utilization
}

\begin{abstract}
Meng-Long Hu ${ }^{1,2}$, Jian Zha ${ }^{1,2}$, Lin-Wei He ${ }^{1,2}$, Ya-Jin Lv ${ }^{1,2}$, Ming-Hua Shen ${ }^{1,2}$, Cheng Zhong ${ }^{3}$, Bing-Zhi $\mathrm{Li}^{1,2 *}$ and Ying-Jin Yuan ${ }^{1,2}$

${ }^{1}$ Key Laboratory of Systems Bioengineering (Ministry of Education), School of Chemical Engineering and Technology, Tianjin University, Tianjin, China, ${ }^{2}$ Collaborative Innovation Center of Chemical Science and Engineering (Tianjin), Tianjin University, Tianjin, China, ${ }^{3}$ Key Laboratory of Industrial Fermentation Microbiology (Ministry of Education), Tianjin University of Science and Technology, Tianjin, China
\end{abstract}

OPEN ACCESS

Edited by:

Peter Neubauer,

Technische Universität Berlin,

Germany

Reviewed by:

Martin Siemann-Herzberg,

University of Stuttgart, Germany

Kechun Zhang,

University of Minnesota, USA

Pinar Calik

Middle East Technical University

(METU), Turkey

*Correspondence:

Bing-Zhi Li

bzli@tju.edu.cn

Specialty section:

This article was submitted to Microbiotechnology, Ecotoxicology and Bioremediation,

a section of the journal

Frontiers in Microbiology

Received: 13 September 2015 Accepted: 15 February 2016

Published: 03 March 2016

Citation:

Hu M-L, Zha J, He L-W, LV Y-J,

Shen $M-H$, Zhong C, Li B-Z and

Yuan Y-J (2016) Enhanced

Bioconversion of Cellobiose by Industrial Saccharomyces cerevisiae

Used for Cellulose Utilization.

Front. Microbiol. 7:241.

doi: 10.3389/fmicb.2016.00241
Cellobiose accumulation and the compromised temperature for yeast fermentation are the main limiting factors of enzymatic hydrolysis process during simultaneous saccharification and fermentation (SSF). In this study, genes encoding cellobiose transporter and $\beta$-glucosidase were introduced into an industrial Saccharomyces cerevisiae strain, and evolution engineering was carried out to improve the cellobiose utilization of the engineered yeast strain. The evolved strain exhibited significantly higher cellobiose consumption rate (2.8-fold) and ethanol productivity (4.9-fold) compared with its parent strain. Besides, the evolved strain showed a high cellobiose consumption rate of $3.67 \mathrm{~g} / \mathrm{L} / \mathrm{h}$ at $34^{\circ} \mathrm{C}$ and $3.04 \mathrm{~g} / \mathrm{L} / \mathrm{h}$ at $38^{\circ} \mathrm{C}$. Moreover, little cellobiose was accumulated during SSF of Avicel using the evolved strain at $38^{\circ} \mathrm{C}$, and the ethanol yield from Avicel increased by $23 \%$ from 0.34 to $0.42 \mathrm{~g}$ ethanol $/ \mathrm{g}$ cellulose. Overexpression of the genes encoding cellobiose transporter and $\beta$-glucosidase accelerated cellobiose utilization, and the improvement depended on the strain background. The results proved that fast cellobiose utilization enhanced ethanol production by reducing cellobiose accumulation during SSF at high temperature.

Keywords: synthetic biology, cellobiose utilization, industrial strain, evolution engineering, simultaneous saccharification and fermentation

\section{INTRODUCTION}

Cellulosic ethanol is widely recognized as a potential alternative fuel for its renewable, environmental and strategic attributes (Zhong et al., 2010). Simultaneous saccharification and fermentation (SSF) is one of the important processes for cellulosic ethanol production (Hahn-Hägerdal et al., 2006; Zhu et al., 2015). Combining the consumption and release of glucose, SSF improves the efficiency of enzymatic hydrolysis compared with separate hydrolysis and fermentation (SHF; Tomás-Pejó et al., 2008). The entire SSF process is carried out in a single reactor, thereby curbs the equipment costs and saves energy (Brethauer and Wyman, 2010). Despite these advantages, the cellobiose accumulation and the different optimal temperatures of cellulolytic enzymes (around $50^{\circ} \mathrm{C}$ ) and yeast fermentation (around $30^{\circ} \mathrm{C}$ ) are the key issues to further improve SSF efficiency (Olofsson et al., 2008; Zhu et al., 2014). 
In SSF the traditional saccharification process relies on the addition of a cellulase cocktail consisting of endoglucanases (EG), cellobiohydrolases (CBH), and $\beta$-glucosidases (BGL; Li B. Z. et al., 2010; Zhang et al., 2012). During the process, cellulose is firstly degraded into glucose by the synergistic action of three classes of enzymes and then the glucose is converted into ethanol by the fermentation strains (Horn et al., 2012). However, fungal cellulases exhibit weak $\beta$-glucosidase (BGL) activity which results in slow degradation of cellobiose into glucose, thus cellobiose is accumulated during SSF (Chauve et al., 2010). Since cellobiose is one of the significant inhibitors of cellulases (Andrić et al., 2010; Hsieh et al., 2014), the overall rate and efficiency of enzymatic hydrolysis of cellulose is inhibited by the accumulation of cellobiose (Singhania et al., 2013; Qin et al., 2014). To increase the efficiency of enzymatic hydrolysis, extra BGL needs to be added in during the enzymatic hydrolysis, which results in a higher cost (Zhang et al., 2010). In order to reduce the cost of enzymes in ethanol production, microorganisms capable of utilizing cellobiose have been developed (la Grange et al., 2010). Saccharomyces cerevisiae is preferred in the industrial ethanol production due to its robustness, industrial-scale and high ethanol productivity (Nielsen et al., 2013). Since native $S$. cerevisiae cannot ferment cellobiose, three strategies have been developed for heterologous cellobiose utilization. In the first strategy, S. cerevisiae was engineered to secrete or display a BGL to hydrolyze cellobiose to glucose outside the cells (Matsuoka et al., 2014; Treebupachatsakul et al., 2016). The phosphorolytic pathway is the second strategy which involves heterologous expression of a cellobiose phosphorylase and a lactose permease or a cellobiose transporter (CDT). The cellobiose is transported into the cell via the lactose permease or CDT and then cleaved by the cellobiose phosphorylase in the presence of inorganic phosphate to produce glucose and $\alpha$-glucose-1-phosphate (Sadie et al., 2011; Ha et al., 2013a; Chomvong et al., 2014). The third strategy is the hydrolytic pathway. Heterologous cellobiose hydrolytic pathway consisting of a CDT and a BGL was introduced into a laboratory S. cerevisiae strain (Galazka et al., 2010). In the engineered yeast strain, cellobiose is transported into the cell by the CDT and hydrolyzed to glucose by the BGL and then metabolized by the cell. However, the ethanol yield and cellobiose fermentative efficiency are not high enough when using engineered yeast strains with heterologous pathways, and further engineering is required to improve the cellobiose utilization.

Another concern of SSF is the mismatch between the optimal temperatures for enzymatic hydrolysis (about $50^{\circ} \mathrm{C}$ ) and yeast fermentation (about $30^{\circ} \mathrm{C}$; Weber et al., 2010). To reach a compromise between the optimal temperatures for enzymes and yeast cells, SSF is commonly performed at lower temperature which leads to a poor hydrolysis efficiency of the substrate (Hasunuma and Kondo, 2012). Therefore, thermotolerant microbial strains capable of producing ethanol at higher temperatures are essential for the improvement of SSF efficiency (Lin and Tanaka, 2006). Thermotolerant yeast strains, including Kluyveromyces fragilis (Hari Krishna et al., 2001), Pichia kudriavzevii (Koutinas et al., 2016), Hansenula polymorpha (Kurylenko et al., 2014), Kluyveromyces marxianus
(Arora et al., 2015; Wu et al., 2016) and other newly isolated Kluyveromyces sp. (Narra et al., 2015) have been used in SSF at temperatures close to the optimal temperature for enzymatic hydrolysis. Many studies have focused on S. cerevisiae strains due to the robustness for ethanol production, and thermotolerant strains were obtained and applied in SSF (Park et al., 2010; Chu et al., 2012; Cha et al., 2015). In order to further improve the enzymatic hydrolysis efficiency during SSF, thermotolerant $S$. cerevisiae capable of rapid cellobiose utilization is required.

In this study, cellobiose utilization pathway was constructed in a thermotolerant industrial S. cerevisiae strain. An evolved strain SyBE001603 was obtained through evolution engineering and characterized at different temperatures $\left(30-42^{\circ} \mathrm{C}\right)$. The efficiency of SSF was significantly improved at high temperature by using strain SyBE001603 with fast cellobiose utilization.

\section{MATERIALS AND METHODS}

\section{Strains and Culture Media}

Escherichia coli DH5 $\alpha$ was used as the host strain for gene cloning and manipulation. The $S$. cerevisiae strain L2612 used as the host for DNA assembly was a gift from Professor Thomas Jeffries at University of Wisconsin-Madison (Zha et al., 2013). The industrial S. cerevisiae strain SyBE001601 used as chassis in this study was a commercial strain and reported in our previous study (Ding et al., 2012). Yeast strains and plasmids used in this work are described in Table $\mathbf{1}$.

E. coli was cultured in Luria-Bertani medium $(5 \mathrm{~g} / \mathrm{L}$ yeast extract, $10 \mathrm{~g} / \mathrm{L}$ tryptone, $10 \mathrm{~g} / \mathrm{L} \mathrm{NaCl}$ ) at $37^{\circ} \mathrm{C}$ and $250 \mathrm{rpm}$, and $100 \mathrm{mg} / \mathrm{mL}$ of ampicillin was added to the medium when necessary. Yeast strains were cultivated in YP medium $(10 \mathrm{~g} / \mathrm{L}$ yeast extract, $20 \mathrm{~g} / \mathrm{L}$ peptone) supplemented with $20 \mathrm{~g} / \mathrm{L}$ glucose (YPD) or $20 \mathrm{~g} / \mathrm{L}$ cellobiose (YPC), at $30^{\circ} \mathrm{C}$ and $200 \mathrm{rpm}$ (for aerobic growth) or $150 \mathrm{rpm}$ (for oxygen limited conditions). SC agar medium containing $6.7 \mathrm{~g} / \mathrm{L}$ yeast nitrogen base, $2 \mathrm{~g} / \mathrm{L}$ appropriate nucleotides and amino acids, $20 \mathrm{~g} / \mathrm{L}$ cellobiose and $20 \mathrm{~g} / \mathrm{L}$ agar was used for selection of transformants.

\section{Plasmid and Strain Construction}

The plasmids were constructed as follows. The plasmid pRS426$c d t-1$ was linearized by restriction enzyme NgoMIV. The expression cassette of BGL gene with the PGK1 promoter and the CYC1 terminator was amplified by PCR using the forward primer 426-PGK1-F and the reverse primer 426-CYC1-R (Table $\mathrm{S} 1$ ). Then the amplified expression cassette was assembled into the linearized plasmid pRS426-cdt-1 by the DNA assembler method (Shao et al., 2009) and the plasmid pRS426-cdt-1-gh11 was gained. For plasmid pRS415-cdt-1 and pRS415-gh1-1, the plasmid pRS415 was linearized by restriction enzyme XbaI and XmaI. The expression cassette of CDT gene and BGL gene with the PGK1 promoter and the CYC1 terminator were amplified by PCR with primer 415-PGK1-F and the reverse primer 415CYC1-R (Table S1) and then were assembled into the linearized plasmid pRS415 by the DNA assembler method. The resulting plasmids were extracted and transformed into target strain by the LiAc/SSDNA/PEG procedure (Gietz et al., 1995) and transformants were selected on SC agar plates. The isolation of 
TABLE 1 | Strains and plasmids used in this study.

\begin{tabular}{|c|c|c|}
\hline Strains and plasmids & Description & Source or references \\
\hline \multicolumn{3}{|l|}{ PLASMIDS } \\
\hline pRS426-cdt-1 & $\mathrm{P}_{\mathrm{PGK} 1}-\mathrm{cdt}-1-\mathrm{T}_{\mathrm{CYC} 1}$ & Galazka et al., 2010 \\
\hline pRS425-gh1-1 & $P_{P G K 1}-g h 1-1-T_{C Y C 1}$ & Galazka et al., 2010 \\
\hline pRS426-cdt-1-gh1-1 & $P_{P G K 1}-c d t-1-T_{C Y C 1}-P_{P G K 1}-g h 1-1-T_{C Y C 1}$ & This study \\
\hline pRS415 & & Brachmann et al., 1998 \\
\hline pRS415-cdt-1 & $\mathrm{P}_{\mathrm{PGK} 1}-\mathrm{cdt}-1-\mathrm{T}_{\mathrm{CYC1}}$ & This study \\
\hline pRS415-gh1-1 & $P_{P G K 1}-g h 1-1-T_{C Y C 1}$ & This study \\
\hline \multicolumn{3}{|l|}{ STRAINS } \\
\hline SyBE001601 & Angel Yeast, Product No. 80000012 & Ding et al., 2012 \\
\hline SyBE001602 & SyBE001601, pRS426-cdt-1-gh1-1 & This study \\
\hline SyBE001603 & Evolved from SyBE001602 & This study \\
\hline SyBE001604 & SyBE001601, isolated plasmid from SyBE001603 & This study \\
\hline L2612 & MATa leu2-3 leu2-112 ura3-52trp1-298 can1 cyn1 gal+ & Zha et al., 2013 \\
\hline L2612-Cell & L2612/pRS426-cdt-1-gh1-1 & This study \\
\hline L2612-Cell+CDT & L2612/pRS426-cdt-1-gh1-1/pRS415-cdt-1 & This study \\
\hline L2612-Cell+BGL & L2612/pRS426-cdt-1-gh1-1/pRS415-gh1-1 & This study \\
\hline BY4741 & MATa his3 $\Delta 1$ leu2 $\Delta 0$ met15 $\Delta 0$ ura3 $\Delta 0$ & Brachmann et al., 1998 \\
\hline BY4741-Cell & BY4741/pRS426-cdt-1-gh1-1 & This study \\
\hline BY4741-Cell+CDT & BY4741/pRS426-cdt-1-gh1-1/pRS415-cdt-1 & This study \\
\hline BY4741-Cell+BGL & BY4741/pRS426-cdt-1-gh1-1/pRS415-gh1-1 & This study \\
\hline BY4742 & MAT a his $3 \Delta 1$ leu $2 \Delta 0$ lys $2 \Delta 0$ ura3 $\Delta 0$ & Brachmann et al., 1998 \\
\hline BY4742-Cell & BY4742/pRS426-cdt-1-gh1-1 & This study \\
\hline BY4742-Cell+CDT & BY4742/pRS426-cdt-1-gh1-1/pRS415-cdt-1 & This study \\
\hline BY4742-Cell+BGL & BY4742/pRS426-cdt-1-gh1-1/pRS415-gh1-1 & This study \\
\hline YSG50 & MAT $\alpha$ ade2-1 ade3 $\Delta 22$ ura3-1 his3-11 15 trp1-1 leu2-3 112 and can1-100 & Shao et al., 2009 \\
\hline YSG50-Cell & YSG50/pRS426-cdt-1-gh1-1 & This study \\
\hline YSG50-Cell+CDT & YSG50/pRS426-cdt-1-gh1-1/pRS415-cdt-1 & This study \\
\hline YSG50-Cell+BGL & YSG50/pRS426-cdt-1-gh1-1/pRS415-gh1-1 & This study \\
\hline CEN.PK2-1C & MATa ura3-52 trp1-289 leu2-3_112 his3D1 MAL2-8 c SUC2 & From EUROSCARF \\
\hline CEN.PK2-1C-Cell & CEN.PK2-1C/pRS426-cdt-1-gh1-1 & This study \\
\hline CEN.PK2-1C-Cell+CDT & CEN.PK2-1C/pRS426-cdt-1-gh1-1/pRS415-cdt-1 & This study \\
\hline CEN.PK2-1C-Cell+BGL & CEN.PK2-1C/pRS426-cdt-1-gh1-1/pRS415-gh1-1 & This study \\
\hline
\end{tabular}

the plasmid from the evolved strain was performed by Yeast Plasmid Kit (Tiangen, Beijing, China) and amplified through E. coli transformation. Then the plasmid was extracted from E. coli and verified by sequencing.

\section{Evolution Engineering}

To improve the efficiency of the cellobiose utilization of strain SyBE001602, an evolution engineering approach was performed. The yeast strain SyBE001602 was cultured in YPC media till stationary phase, and then transferred to a new flask containing the same culture medium at an initial $\mathrm{OD}_{600}$ of 0.1 . The serial subcultures were repeated 20 times for nearly 50 days until the specific growth rate of the yeast culture remained almost constant. After 20 times subculture, cells from shake flasks were streaked on YPC plates to isolate single colonies. Twenty colonies with the largest size were chosen and cultivated in YPC medium for $48 \mathrm{~h}$, and then each colony was inoculated into $3 \mathrm{~mL}$ YPC medium in rubber-sealed test tubes at an initial $\mathrm{OD}_{600}$ of 0.1 .
All the test tubes were cultivated for $12 \mathrm{~h}\left(30^{\circ} \mathrm{C}\right.$ and $\left.150 \mathrm{rpm}\right)$. The metabolites were analyzed regularly after cultivation and the colony with the highest ethanol production rate and cellobiose consumption rate was isolated and named SyBE001603.

\section{Batch Fermentation}

Yeast cells were cultivated in YPC medium to prepare inoculums for fermentation and cells were harvested by centrifugation (4000 rpm, $5 \mathrm{~min}$ ) at mid-exponential phase. Flask fermentation experiments were performed in $50 \mathrm{~mL}$ YP medium containing 40 or $80 \mathrm{~g} / \mathrm{L}$ cellobiose using $150 \mathrm{~mL}$ shaking flask (sealed by a rubber stopper with a syringe needle) at an initial $\mathrm{OD}_{600}$ of 1.0 under oxygen limited conditions. All the flask fermentations were performed in duplicates. Bioreactor fermentations were performed in $400 \mathrm{~mL}$ YP medium containing $80 \mathrm{~g} / \mathrm{L}$ cellobiose in a $0.7-\mathrm{L}$ bioreactor (Bailun, Shanghai, China) at $38^{\circ} \mathrm{C}$ with an agitation speed of $200 \mathrm{rpm}$ under oxygen limited conditions. Initial cell densities were adjusted to $\mathrm{OD}_{600} \sim 1$. 

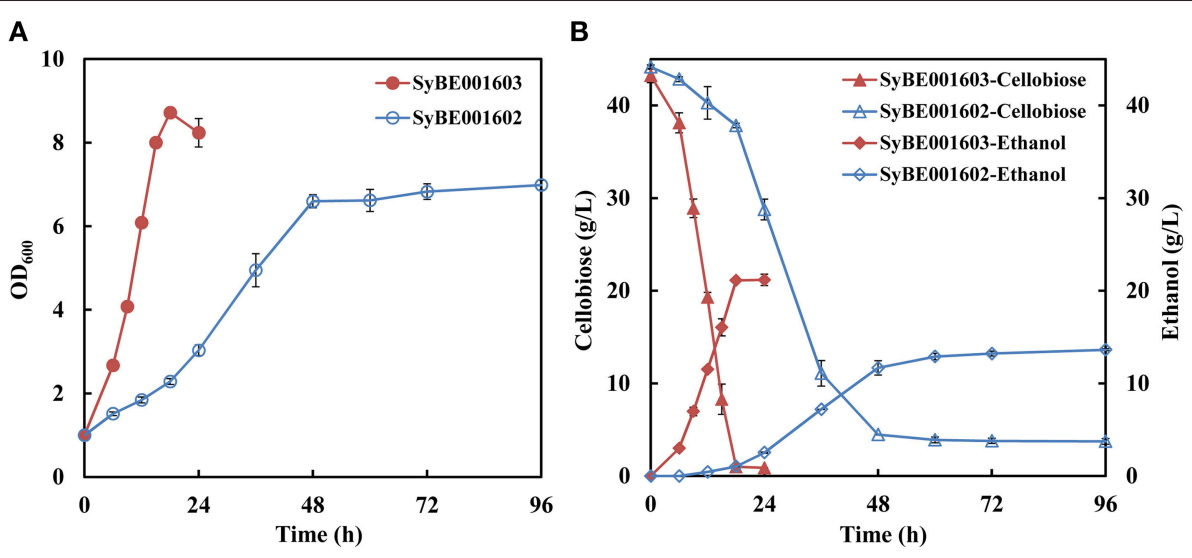

FIGURE 1 | Growth (A) and fermentation performance (B) of the parent strain SyBE001602 and evolved strain SyBE001603.

\section{Simultaneous Saccharification and Fermentation}

The cellulase used for enzymatic hydrolysis was Celluclast (Sigma-Aldrich, St. Louis, MO, USA) with cellulase activity of approximately $80 \mathrm{FPU} / \mathrm{mL}$ and BGL activity of $20.1 \mathrm{CBU} / \mathrm{mL}$ (Ruffell et al., 2010). SSF experiments were conducted in $50 \mathrm{~mL}$ YP medium with 4\% (w/v) Avicel (Sigma-Aldrich, St. Louis, MO, USA) with cellulase enzyme loadings of $10 \mathrm{FPU} / \mathrm{g}$ of glucan. The $\mathrm{pH}$ was adjusted to 4.8 by citrate buffer sterilized with $0.22 \mu \mathrm{m}$ filter. The YP medium was sterilized at $121^{\circ} \mathrm{C}$ for $20 \mathrm{~min}$, and the Avicel was sterilized by UV light. The fermentation condition was the same with the flask fermentation method above.

\section{Analysis of Substrates and Fermentation Products}

Cell growth was monitored by optical density (OD) at 600 nm using a Model 722 grating spectrometer (Shanghai No. 3 Analysis Equipment Factory, Shanghai, China). Samples were taken periodically from the cultures and centrifuged at 10,000 rpm for $5 \mathrm{~min}$ to collect supernatant for metabolite analysis. Cellobiose, glucose and ethanol in the samples were determined by high performance liquid chromatography (HPLC) system consisting of a Waters 1515 pump (Waters, Milford, MA, USA), a Bio-Rad HPX-87H column (Bio-Rad, Hercules, CA, USA) and a Waters 2414 refractive index detector (Waters, Milford, MA, USA). The HPLC separation was operated at $65^{\circ} \mathrm{C}$ with $5 \mathrm{mM}$ $\mathrm{H}_{2} \mathrm{SO}_{4}$ as mobile phase at a flow rate of $0.6 \mathrm{~mL} / \mathrm{min}$ (Zha et al., 2012).

\section{Real-Time PCR Analysis}

Yeast cells were cultivated under the same condition with flask fermentation at $30^{\circ} \mathrm{C}$ in YP medium with $40 \mathrm{~g} / \mathrm{L}$ cellobiose. The cells were harvested at $12 \mathrm{~h}$ and washed by ice-cold phosphatebuffered saline. The total RNA was immediately extracted using TRIzol reagent (Invitrogen, Carlsbad, CA, USA) and reversetranscribed into cDNA using RevertAid First Strand cDNA Synthesis Kit (Thermo Fisher Scientific, Waltham, MA, USA)
TABLE 2 | Comparison of the fermentation profiles of the parent strain SyBE001602 and evolved strain SyBE001603.

\begin{tabular}{lccc}
\hline & $\begin{array}{c}\text { Cellobiose } \\
\text { consumption } \\
\text { (g/L/h) }\end{array}$ & $\begin{array}{c}\text { Ethanol } \\
\text { productivity } \\
\mathbf{( g / L / h )}\end{array}$ & $\begin{array}{c}\text { Yield } \\
\text { (g ethanol/) } \\
\mathbf{g} \text { cellobiose) }\end{array}$ \\
\hline SyBE001602 & $0.83 \pm 0.01$ & $0.24 \pm 0.02$ & $0.34 \pm 0.00$ \\
SyBE001603 & $2.35 \pm 0.04^{\star \star *}$ & $1.17 \pm 0.01^{\star * *}$ & $0.50 \pm 0.01^{\star}$ \\
\hline
\end{tabular}

Results are expressed as mean \pm standard error of the mean. Significance levels of Students t-test: ${ }^{*} P<0.05,{ }^{* \star *} P<0.001$.

following the manufacturer's instructions. Quantitative Realtime PCR was performed in the ABI Step one Plus Real-Time PCR system (Applied Biosystems, Foster City, CA, USA). The oligos used in the PCR were listed in Table S1. Three biological replicates were prepared for each gene. The data was normalized using ACT1 as the internal standard and analyzed according to the $2^{-\Delta \Delta C T}$ method (Zha et al., 2014).

\section{RESULTS}

\section{Improved Cellobiose Utilization through Evolution Engineering}

A heterologous cellobiose utilization pathway consisting of CDT and BGL was introduced into industrial $S$. cerevisiae strain SyBE001601. The obtained strain, named SyBE001602, was able to produce ethanol when using cellobiose as substrate, but the growth rate and fermentation efficiency was low (Figure 1).

Evolution engineering was carried out to enhance the cellobiose utilization of the engineered strain. After the evolution a strain with rapid cellobiose utilization capability was obtained and named SyBE001603. A comparison of the evolved and parent strain was performed at $30^{\circ} \mathrm{C}$ with $40 \mathrm{~g} / \mathrm{L}$ cellobiose. SyBE001603 consumed cellobiose quickly and completely in around $18 \mathrm{~h}$, while SyBE001602 was not able to ferment all the cellobiose even after $96 \mathrm{~h}$ with $3.7 \mathrm{~g} / \mathrm{L}$ cellobiose left at the end of fermentation (Figure 1B). In the fermentation with SyBE001602, the accumulation of cellodextrins was observed 
TABLE 3 | Cellobiose consumption rate, ethanol productivity, and yield at temperature grads of $30,34,38$, and $42^{\circ} \mathrm{C}$.

\begin{tabular}{lllll}
\hline Temperature $\left({ }^{\circ} \mathbf{C}\right)$ & $\mathbf{3 0}$ & $\mathbf{3 4}$ & $\mathbf{3 8}$ & $\mathbf{4 2}$ \\
\hline $\begin{array}{l}\text { Maximum specific } \\
\text { growth rate }(/ \mathrm{h})\end{array}$ & $0.16 \pm 0.01$ & $0.18 \pm 0.02$ & $0.13 \pm 0.02$ & $0.06 \pm 0.01^{\star}$ \\
$\begin{array}{l}\text { Cellobiose } \\
\text { consumption (g/L/h) }\end{array}$ & $2.19 \pm 0.00$ & $2.61 \pm 0.02^{\star *}$ & $2.19 \pm 0.00$ & $1.28 \pm 0.00^{\star \star *}$ \\
$\begin{array}{l}\text { Ethanol productivity } \\
\text { (g/L/h) }\end{array}$ & $1.09 \pm 0.03$ & $1.27 \pm 0.03^{*}$ & $1.05 \pm 0.02$ & $0.61 \pm 0.03^{\star *}$ \\
$\begin{array}{l}\text { Yield }(\mathrm{g} \text { ethanol/g } \\
\text { cellobiose) }\end{array}$ & $0.50 \pm 0.03$ & $0.50 \pm 0.01$ & $0.50 \pm 0.01$ & $0.49 \pm 0.00$ \\
\end{tabular}

Results are expressed as mean \pm standard error of the mean. Significance levels of Students t-test: ${ }^{\star} P<0.05,{ }^{\star \star} P<0.01,{ }^{\star \star \star} P<0.001$.

(Figure S1), which led to a low ethanol yield of $0.34 \mathrm{~g}$ ethanol/g cellobiose (Table 2). While almost no cellodextrins accumulation was observed in the fermentation with SyBE001603. The evolved strain SyBE001603 showed 2.8- and 4.9-fold higher cellobiose consumption rate and ethanol productivity than strain SyBE001602 (Table 2). The ethanol yield increased by $47 \%$ and reached $0.50 \mathrm{~g}$ ethanol $/ \mathrm{g}$ cellobiose. According to the results, the cellobiose metabolism was significantly optimized by evolution engineering.

\section{Effect of Temperature on Cellobiose Fermentation}

To investigate the effect of temperature on cellobiose utilization, fermentation with SyBE001603 was performed respectively at 30, 34,38 , and $42^{\circ} \mathrm{C}$. The strain exhibited the highest growth rate and cellobiose consumption rate at $34^{\circ} \mathrm{C}$ (Table 3 ). Cellobiose in the medium was completely consumed in $15 \mathrm{~h}$ and the average cellobiose consumption rate reached $2.61 \mathrm{~g} / \mathrm{L} / \mathrm{h}$. Interestingly, the ethanol production rates and cellobiose consumption rates were almost the same at 30 and $38^{\circ} \mathrm{C}$. Even at $42^{\circ} \mathrm{C}, 40 \mathrm{~g} / \mathrm{L}$ cellobiose was consumed completely within $36 \mathrm{~h}$, with an ethanol production rate of $0.61 \mathrm{~g} / \mathrm{L} / \mathrm{h}$. The ethanol yield was around $0.49 \sim 0.50 \mathrm{~g}$ ethanol $/ \mathrm{g}$ cellobiose at different temperature and no negative effect of high temperature on the ethanol yield was observed in this study. These results suggested that the strain SyBE001603 exhibited an advantage of thermotolerance in ethanol fermentation when using cellobiose as the sole carbon source.

Since the strain SyBE001603 showed the highest cellobiose consumption rate at $34^{\circ} \mathrm{C}$, fermentation with a high cellobiose concentration of $80 \mathrm{~g} / \mathrm{L}$ was conducted at $34^{\circ} \mathrm{C}$ to further test its cellobiose utilization capability. The cellobiose consumption rate reached $3.67 \mathrm{~g} / \mathrm{L} / \mathrm{h}$ and almost all the cellobiose was consumed at $21 \mathrm{~h}$ (Figure 2). The ethanol production rate reached $1.73 \mathrm{~g} / \mathrm{L} / \mathrm{h}$ and the yield was $0.49 \mathrm{~g}$ ethanol/g cellobiose.

\section{Effect of pH on Cellobiose Fermentation}

Generally, the optimum $\mathrm{pH}$ of cellulases is considered around 4.8 (Caminal et al., 1985). The industrial strain with tolerance toward low $\mathrm{pH}$-values can facilitate efficient saccharification and minimize the risk of contamination (Olofsson et al., 2008).

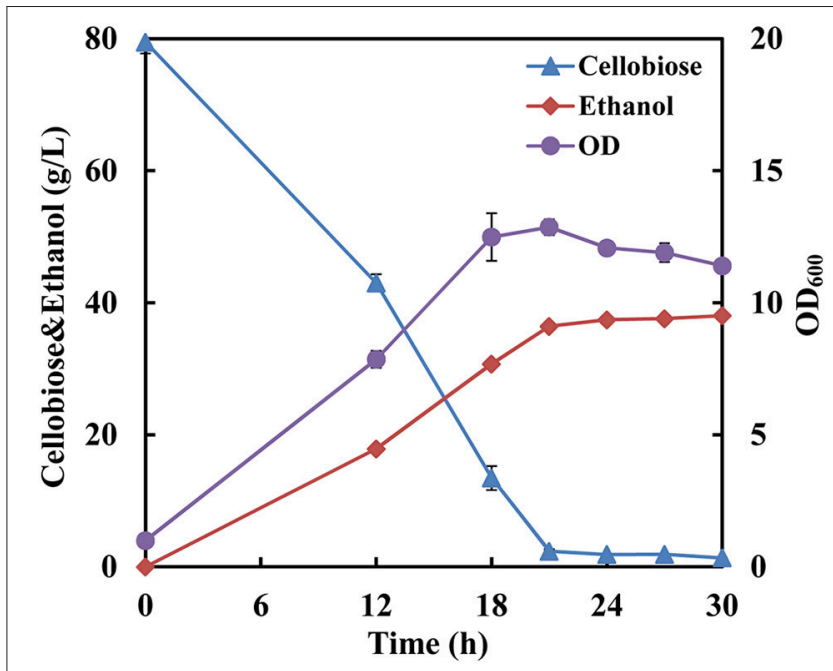

FIGURE 2 | Fermentation performance of the strain SyBE001603 with high cellobiose concentration.

To investigate the effect of $\mathrm{pH}$ on cellobiose fermentation of strain SyBE001603, fermentation processes were performed at different $\mathrm{pH}$ of $4.5,5.0,5.5$, and 6.0 in bioreactors at $38^{\circ} \mathrm{C}$ (Figure 3). The strain SyBE001603 presented the highest cellobiose consumption rate of $3.04 \mathrm{~g} / \mathrm{L} / \mathrm{h}$ at $\mathrm{pH} 5.5$ and $\mathrm{pH}$ 6.0 and almost all the cellobiose was consumed within $24 \mathrm{~h}$. The cellobiose consumption rate reached $2.72 \mathrm{~g} / \mathrm{L} / \mathrm{h}$ at $\mathrm{pH} 5.0$, which was a bit lower than those at $\mathrm{pH} 5.5$ and $\mathrm{pH}$ 6.0. At $\mathrm{pH}$ 4.5 the cellobiose was consumed completely within $42 \mathrm{~h}$ with a consumption rate of $1.87 \mathrm{~g} / \mathrm{L} / \mathrm{h}$. As a result, strain SyBE001603 can be tolerant to a $\mathrm{pH}$ as low as 4.5 and has better fermentation performance at $\mathrm{pH} 5.0 \sim 6.0$.

\section{Simultaneous Saccharification and Fermentation of Cellulose}

During SSF, enzymatic hydrolysis and yeast fermentation were significantly affected by temperature. SSF and enzymatic hydrolysis were conducted at a temperature grads from 30 to $42^{\circ} \mathrm{C}$ to determine the optimum temperature. During the saccharification process $12.7 \mathrm{~g} / \mathrm{L}$ and $13.4 \mathrm{~g} / \mathrm{L}$ equivalent glucose were released at 30 and $34^{\circ} \mathrm{C}$, respectively, while at $38^{\circ} \mathrm{C}$ the rate was $46.6 \%$ higher than that at $30^{\circ} \mathrm{C}$ (Figure $4 \mathrm{~A}$ ). Increases in temperature led to higher conversion rate of Avicel in enzymatic hydrolysis. Among the temperature grads, the optimal temperature for enzymatic hydrolysis was $42^{\circ} \mathrm{C}$ and $22.5 \mathrm{~g} / \mathrm{L}$ equivalent glucose was released in total. However, the optimal temperature for strain SyBE001603 was $34^{\circ} \mathrm{C}$ (Table 3). In SSF process the ethanol production performance at higher temperature were better than at $30^{\circ} \mathrm{C}$ (Figure 4B). Till $144 \mathrm{~h}$ $15.8 \mathrm{~g} / \mathrm{L}$ ethanol was produced at $38^{\circ} \mathrm{C}$ and $15.7 \mathrm{~g} / \mathrm{L}$ ethanol was produced at $42^{\circ} \mathrm{C}$, while only $12.9 \mathrm{~g} / \mathrm{L}$ and $14.3 \mathrm{~g} / \mathrm{L}$ ethanol was produced at $30^{\circ} \mathrm{C}$ and at $34^{\circ} \mathrm{C}$ during the fermentation, respectively. During the process the strain at $38^{\circ} \mathrm{C}$ showed better fermentation performance than other temperature, thus $38^{\circ} \mathrm{C}$ was suggested to be the optimum temperature for SyBE001603 
in SSF, and the efficiency of enzymatic hydrolysis was obviously accelerated by SSF.

SyBE001603 and its parent strain SyBE001601 were applied in SSF at $38^{\circ} \mathrm{C}$. For SyBE001601 obvious cellobiose accumulation was observed at the initial stage and a peak value of $3.65 \mathrm{~g} / \mathrm{L}$ appeared at $6 \mathrm{~h}$ (Figure 5A) while for SyBE001603 cellobiose was consumed and much less cellobiose (below $1 \mathrm{~g} / \mathrm{L}$ ) was accumulated. At $6 \mathrm{~h}$ when the cellobiose accumulation reached

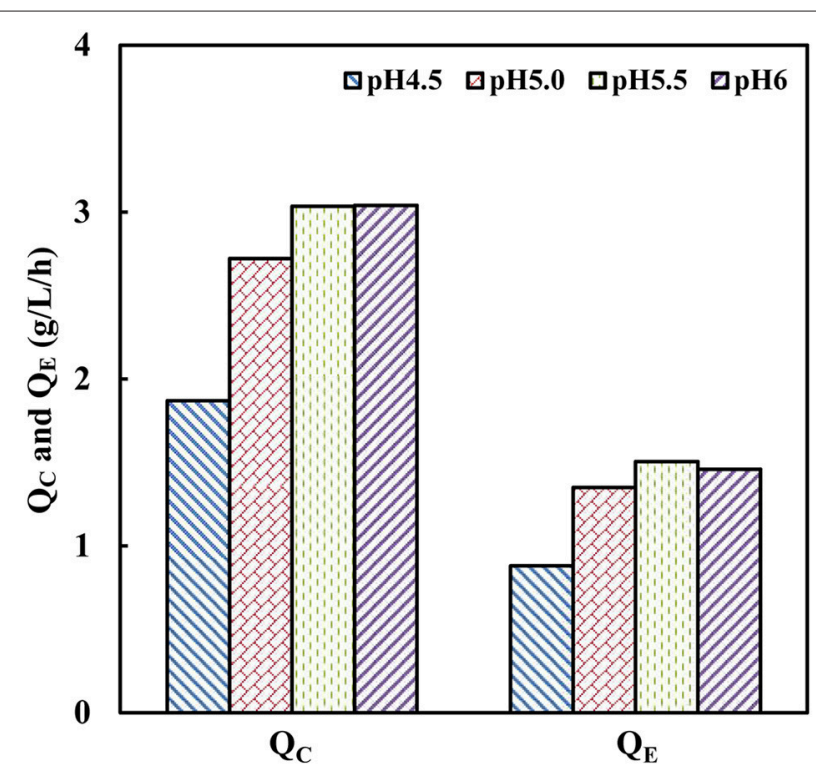

FIGURE 3 | Effects of pH on cellobiose fermentation by SyBE001603. $Q_{C}$, the average cellobiose consumption rate; $Q_{E}$, the average ethanol production rate. a peak value, the ethanol productivity of SyBE001603 was 2.6-fold higher than SyBE001601. The ethanol yield increased $23 \%$ from 0.34 to $0.42 \mathrm{~g}$ ethanol $/ \mathrm{g}$ cellulose (Figure 5B). These results suggest that the inhibition of cellobiose and glucose on cellulase was significantly relieved by SSF with strain SyBE001603.

\section{Rational Optimization of Cellobiose Utilization}

To further explore the differences between the parent strain and evolved strain which led to higher ethanol fermentation efficiency, the relative transcription levels of the CDT gene and the BGL gene in strain SyBE001603 and SyBE001602 were measured by Real-time PCR. The CDT gene exhibited dramatically higher expression level in SyBE001603, which increased 5.74-fold compared to SyBE001602, and the BGL gene expression level increased 0.21 -fold (Figure S2).

In order to investigate whether or not the increased expression levels of the CDT and BGL gene might influence the overall cellobiose utilization, five laboratory S. cerevisiae strains, BY4741, BY4742, YSG50, CEN.PK2-1C and L2612 were used as chassis strains to overexpress the CDT and BGL gene. The plasmid pRS426-cdt-1-gh1-1 was transformed into the five parent strains, then the single-copy plasmids pRS415-cdt-1 and pRS415-gh1-1 were introduced into the resulting strains to overexpress the CDT and BGL gene, respectively. After overexpression of the CDT and BGL gene, the cellobiose utilization was improved obviously (Table 4). The improvement of cellobiose utilization was the most significant in BY4741 chassis. The cellobiose consumption rate of strain BY4741-Cell+CDT reached $0.98 \mathrm{~g} / \mathrm{L}$ and increased $42 \%$ compared with its parent strain $(0.69 \mathrm{~g} / \mathrm{L})$, and the cellobiose consumption rate of strain BY4741-Cell+BGL increased 23.5\%. When overexpressing the gene in BY4742-Cell, the cellobiose
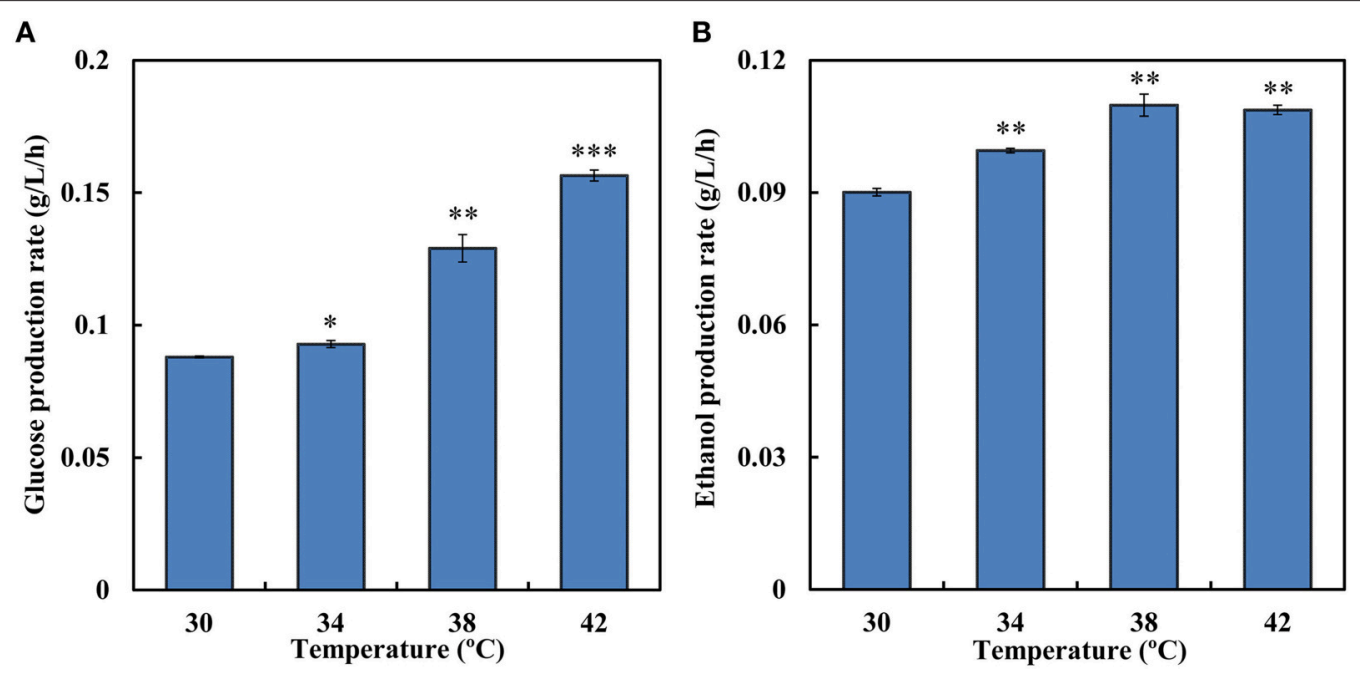

FIGURE 4 | (A) The average equivalent glucose production rate in enzymatic hydrolysis at different temperature (0-144 h). (B) The average ethanol production rate during simultaneous saccharification and fermentation of SyBE001603 at different temperature (0-144 h). The equivalent glucose = the concentration of glucose contained in the released cellobiose + the concentration of glucose released. Results are expressed as mean \pm standard error of the mean. Significance levels of Students $t$-test: ${ }^{\star} P<0.05,{ }^{\star \star} P<0.01,{ }^{* *} P<0.001$. 

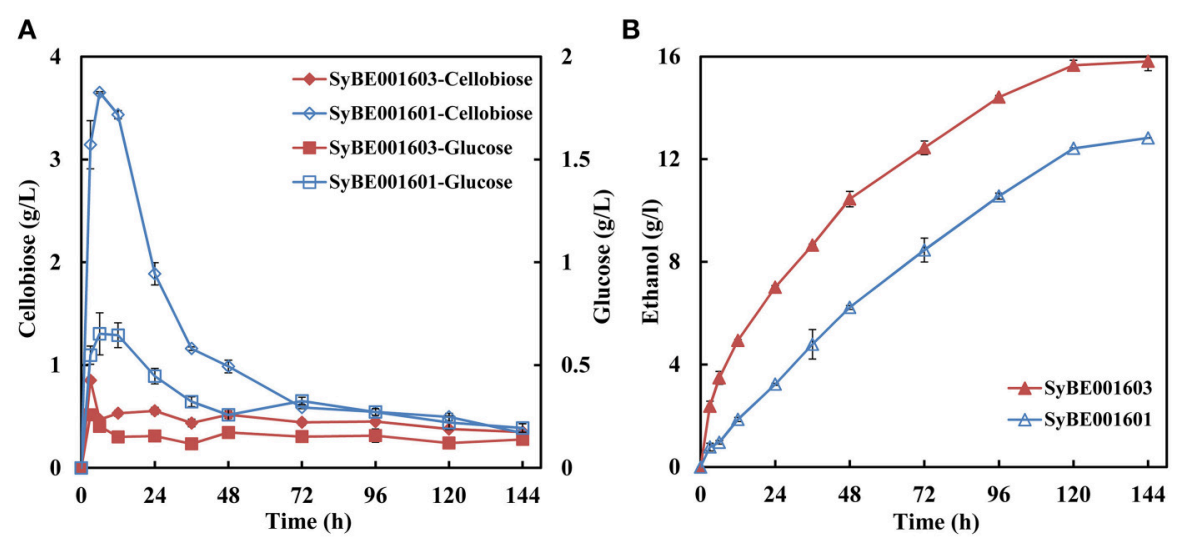

FIGURE 5 | (A) Cellobiose and glucose concentrations and (B) Ethanol concentration during SSF using yeast strains SyBE001601 and SyBE001603 at $38^{\circ} \mathrm{C}$.

TABLE 4 | Effects of overexpressed CDT or BGL gene on the fermentation performance in different chassis strains.

\begin{tabular}{|c|c|c|c|}
\hline & $\begin{array}{c}\text { Cellobiose } \\
\text { consumption } \\
\text { (g/L/h) }\end{array}$ & $\begin{array}{c}\text { Ethanol } \\
\text { productivity } \\
\text { (g/L/h) }\end{array}$ & $\begin{array}{c}\text { Yield } \\
\text { (g ethanol/ } \\
\text { g cellobiose) }\end{array}$ \\
\hline BY4741-Cell & $0.69 \pm 0.01$ & $0.29 \pm 0.00$ & $0.42 \pm 0.00$ \\
\hline BY4741-Cell+CDT & $0.98 \pm 0.01^{\star \star \star}$ & $0.42 \pm 0.01^{\star *}$ & $0.43 \pm 0.00$ \\
\hline BY4741-Cell+BGL & $0.85 \pm 0.00^{\star *}$ & $0.35 \pm 0.01^{*}$ & $0.41 \pm 0.01$ \\
\hline BY4742-Cell & $0.69 \pm 0.00$ & $0.29 \pm 0.01$ & $0.41 \pm 0.01$ \\
\hline BY4742-Cell+CDT & $0.85 \pm 0.00^{* \star}$ & $0.36 \pm 0.01^{*}$ & $0.43 \pm 0.01$ \\
\hline BY4742-Cell+BGL & $0.85 \pm 0.00^{\star \star \star}$ & $0.37 \pm 0.00^{\star *}$ & $0.44 \pm 0.00$ \\
\hline YSG50-Cell & $0.85 \pm 0.00$ & $0.38 \pm 0.01$ & $0.45 \pm 0.02$ \\
\hline YSG50-Cell+CDT & $0.98 \pm 0.00^{\star \star \star}$ & $0.40 \pm 0.01$ & $0.46 \pm 0.02$ \\
\hline YSG50-Cell+BGL & $0.98 \pm 0.00^{\star \star \star}$ & $0.43 \pm 0.02^{*}$ & $0.45 \pm 0.01$ \\
\hline CEN.PK2-1C-Cell & $0.77 \pm 0.00$ & $0.33 \pm 0.01$ & $0.43 \pm 0.01$ \\
\hline CEN.PK2-1C-Cell+CDT & $0.86 \pm 0.01^{\star \star}$ & $0.36 \pm 0.01^{*}$ & $0.42 \pm 0.01$ \\
\hline CEN.PK2-1C-Cell+BGL & $0.87 \pm 0.00^{\star \star \star}$ & $0.37 \pm 0.02^{*}$ & $0.43 \pm 0.02$ \\
\hline L2612-Cell & $0.49 \pm 0.00$ & $0.20 \pm 0.00$ & $0.41 \pm 0.01$ \\
\hline L2612-Cell+CDT & $0.58 \pm 0.00^{\star \star \star}$ & $0.23 \pm 0.00^{\star *}$ & $0.40 \pm 0.01$ \\
\hline L2612-Cell+BGL & $0.57 \pm 0.01^{\star \star}$ & $0.23 \pm 0.00^{\star *}$ & $0.40 \pm 0.01$ \\
\hline
\end{tabular}

Results are expressed as mean \pm standard error of the mean. Significance levels of Students t-test: ${ }^{*} P<0.05,{ }^{\star *} P<0.01,{ }^{* \star *} P<0.001$.

consumption rate of strain BY4742-Cell+CDT and BY4742Cell+BGL both increased $23 \%$. For the other three chassis strains, the overexpression of either the CDT gene or BGL gene led to an improvement at around 13 17\%.

The plasmid pRS426-cdt-1-gh1-1 isolated from the evolved strain was sequenced to search any genetic mutations which may lead to improved cellobiose utilization but no mutations were found on the gene expression cassettes. The isolated plasmid was transformed into the chasis strain SyBE001601 and strain SyBE001604 was obtained to test the cellobiose fermentation property. As a result, compared to strain SyBE001602, SyBE001604 showed indistinctive cellobiose fermentation abilities (Figure S3).

\section{DISCUSSION}

In this study, a thermotolerant industrial $S$. cerevisiae was constructed to utilize cellobiose at a high temperature of $42^{\circ} \mathrm{C}$. Cellulose (Avicel) can be converted efficiently into ethanol by this strain using SSF at $38^{\circ} \mathrm{C}$ with the yield of $0.42 \mathrm{~g}$ ethanol/g cellulose. The strain can be applied in the bioconversion of lignocellulosic materials to valuable bioproducts.

Cellobiose accumulation and its inhibition of cellulases is a daunting problem in the saccharification of pretreated biomass in the SSF (Zhao and Xia, 2009). BGL was supplemented besides cellulases during SSF in order to minimize cellobiose accumulation, which led to the increased cost of cellulolytic enzymes (Lee et al., 2013). In this study, efficient SSF can be achieved at a low cellulase loading of $10 \mathrm{FPU} / \mathrm{g}$ of glucan without the additional BGL by strain SyBE001603. The strategy has been reported by expressing the genes encoding cellobiose transportors discovered in Neurospora crassa, Kluyveromyces lactis, Scheffersomyces stipites, and Penicillium chrysogenum (Galazka et al., 2010; Sadie et al., 2011; Ha et al., 2013b; Bae et al., 2014). The cellobiose is transported into the cell and decomposed into glucose by the glucosidase in vivo, saving the cost for BGL and increasing the SSF efficiency. This method is quite different from the consolidated bioprocess (CBP), in which the constitutive enzymes of the cellulase mixture were expressed in a single cell or consortium to provide the cellulases for hydrolysis of pretreated biomass without addition of extra cellulases (Kim et al., 2013; Kricka et al., 2014). The CBP method can decrease the cost for cellulase cocktails but decreases the saccharification and fermentation efficiency as well since the yields and activities of the cellulases are not high enough (den Haan et al., 2015). The strategy used in this study is very efficient in cellulose hydrolysis and fermentation (Figure 5). Moreover, this alternative can help to bypass glucose repression, achieving simultaneous co-fermentation of cellobiose and xylose (Li S. J. et al., 2010; Ha et al., 2011; Kim et al., 2013).

In previous studies, most cellobiose-fermenting strains were constructed from laboratory strains, which show low tolerance to severe stimulus that are quite common in industrial applications 
such as a high concentration of sugars, high temperatures, and acidic environment. In this study, we used an industrial strain as chassis to express cellobiose pathway. This industrial strain is a commercial strain with robustness to high temperatures and other harsh stimulus, therefore has been applied in industrial ethanol production and brewing in China (Li et al., 2014; Liu Z. H. et al., 2014; Liu et al., 2016).

The ability of cellobiose utilization by the recombinant industrial strain SyBE001602 is very weak. Combinatorial transcriptional engineering and simultaneous engineering of multiple proteins have been applied to optimize the cellobiose pathway successfully (Du et al., 2012; Eriksen et al., 2013). Apart from rational engineering, evolution engineering, a random means, is also effective in improving the utilization ability of non-favored carbon sources (Dhaliwal et al., 2011; Hong et al., 2011; Zha et al., 2014). The evolved strain SyBE001603, obtained after 20 transfers in medium with cellobiose as the sole carbon source, showed significant improvement in cellobiose consumption and ethanol yield (Table 2). Cellodextrins accumulation in the medium was observed during the fermentation by SyBE001602 (Figure S1), which is probably ascribed to the transglycosylation activity of BGL and can reduce ethanol yield and ethanol productivity as well (Ha et al., 2011; Bae et al., 2014; Kim et al., 2014). However, almost no cellodextrins were accumulated during the fermentation of SyBE001603. Accordingly, the ethanol yield reached $0.49 \sim 0.50 \mathrm{~g}$ ethanol/g cellobiose, which is higher than reported in previous studies (Table S2). In addition, obvious cellobiose accumulation was also observed during the preliminary stage of the SSF by SyBE001602 with a peak value of $3.65 \mathrm{~g} / \mathrm{L}$ whereas little cellobiose were accumulated for SyBE001603 (Figure 5). Therefore, the cellobiose accumulation is minimized by SyBE001603 during SSF and the inhibition of cellobiose on cellulases can be greatly relieved.

The improvement of cellobiose utilization may be related to the programmed expression of key genes in the cellobiose metabolism (Yuan and Zhao, 2013). In this study, the transcriptional level of CDT was upregulated significantly after evolution engineering (Figure S2). Increased expression of CDT might enhance the transportation of cellobiose into cell. Overexpression of the CDT gene in other five strains also demonstrates that sufficient expression of CDT can improve cellobiose consumption. As the first step of cellular metabolism, cellobiose transport is a rate-limiting step in the whole fermentation (Lian et al., 2014). The result showed that upregulation of BGL gene improved the cellobiose consumption and the ethanol productivity, indicating the important role of BGL in cellobiose metabolism. However, the effects of the two gene overexpressions on the improvement of cellobiose utilization were chassis-dependent, which might be due to the close relationship of cellobiose metabolism and cell-intrinsic metabolism. Besides the heterologous genes, the fermentation performance of $S$. cerevisiae was strongly influenced by the genetic background (Hector et al., 2011; Du et al., 2012). Moreover, since the CDT is reported to have cellodextrin transport abilities (Galazka et al., 2010), the enhanced expression of CDT gene might increase the cellobiose and cellodextrin transportation ability, and the cellodextrin accumulation can be relieved when the cellobiose transport capabilities increased (Ha et al., 2013b). Besides the absolute expression levels of the CDT and BGL genes, the BGL/CDT ratio are a key point to cellobiose utilization (Yuan and Zhao, 2013). After evolution engineering, the ratio of BGL/CDT decreased from 2.50 to 0.45 , leading to a new balance of cellobiose metabolism with higher efficiency.

To explore the underlying mechanism for the evolution the plasmid pRS426-cdt-1-gh1-1 from SyBE001603 was isolated and sequenced, but the sequencing result showed that no mutations occurred in the promoters and gene coding regions. Moreover, the transformant containing the plasmid extracted from SyBE001603 exhibited no significant improvement of cellobiose utilization compared to SyBE001602 (Figure S3). These discoveries indicate that the reprogramming of the transcription and translation process for CDT, BGL, and other relevant genes in the cellobiose metabolism may happen during the evolution. In an earlier study in our lab, the reshuffling of expression pattern for xylose metabolism was observed in the evolved strain without any changes to DNA sequences (Zha et al., 2014). Comparative analysis of the global transcripts and the genomic DNA of SyBE001602 and SyBE001603 will provide more valuable information for additional improvement of cellobiose metabolism.

Thermotolerance is another important issue for yeast strains in SSF (Lin and Tanaka, 2006). Compared with SHF, the efficiency of hydrolysis was lower in SSF because of low temperature compatible with yeast fermentation (Hasunuma and Kondo, 2012). Thereby, numerous attempts including genome shuffling and introducing thermo tolerant devices have been tried to obtain thermotolerant S. cerevisiae strains for SSF (Shi et al., 2009; Liu Y. et al., 2014). In the fermentation at $38^{\circ} \mathrm{C}$, SyBE001603 showed a cellobiose consumption rate of $3.04 \mathrm{~g} / \mathrm{L} / \mathrm{h}$ and an ethanol production rate of $1.50 \mathrm{~g} / \mathrm{L} / \mathrm{h}$, demonstrating the strong resistance of SyBE001603 to a high temperature. The cellobiose consumption rate and the ethanol production rate were 3.67 and $1.73 \mathrm{~g} / \mathrm{L} / \mathrm{h}$ at $34^{\circ} \mathrm{C}$, respectively. To the best of our knowledge, SyBE001603 is the fastest cellobiose-utilizing S. cerevisiae strain at high temperatures ever reported (Table S2). In the future, the thermotolerance of SyBE001603 should be further improved to efficiently work in the SSF at a higher temperature.

The thermotolerant cellobiose-fermenting yeast developed in the present study provides an ideal strain for efficient utilization of cellulose using the SSF process. In the following studies, the strain can be engineered to utilize xylose in the biomass hydrolysates, and some genetic engineering for tolerance would strengthen the potential workhorse (Wang et al., 2015). Then the tolerant strain can be applied in the economic conversion of biomass to ethanol and other valuable chemicals.

\section{CONCLUSION}

Efficient cellobiose utilization is the key to cellulose bioconversion during SSF. Evolution engineering was an 
efficient approach to improve the cellobiose utilization of the engineered yeast strain. The fast cellobiose utilization in industrial yeast enhanced ethanol production by reducing cellobiose accumulation during SSF at high temperature.

\section{AUTHOR CONTRIBUTIONS}

$\mathrm{MH}$ designed the whole program, operated the experiment, analyzed the results and wrote the article. JZ contributed to the design of the program, and helped to construct the engineered strain. LH contributed to the fermentation work. YL gave help about writing and language. MS helped to construct the engineered strain. CZ gave help about writing and dicussion. BL helped about protocol design, experiment operation and writing. YY gave

\section{REFERENCES}

Andrić, P., Meyer, A. S., Jensen, P. A., and Dam-Johansen, K. (2010). Reactor design for minimizing product inhibition during enzymatic lignocellulose hydrolysis: I. Significance and mechanism of cellobiose and glucose inhibition on cellulolytic enzymes. Biotechnol Adv. 28, 308-324. doi: 10.1016/j.biotechadv.2010.01.003

Arora, R., Behera, S., Sharma, N. K., and Kumar, S. (2015). A new search for thermotolerant yeasts, its characterization and optimization using response surface methodology for ethanol production. Front. Microbiol. 6:889. doi: 10.3389/fmicb.2015.00889

Bae, Y. H., Kang, K. H., Jin, Y. S., and Seo, J. H. (2014). Molecular cloning and expression of fungal cellobiose transporters and $\beta$-glucosidase conferring efficient cellobiose fermentation in Saccharomyces cerevisiae. J. Biotechnol. 169, 34-41. doi: 10.1016/j.jbiotec.2013.10.030

Brachmann, C. B., Davies, A., Cost, G. J., Caputo, E., Li, J., Hieter, P., et al. (1998). Designer deletion strains derived from Saccharomyces cerevisiae S288C: a useful set of strains and plasmids for PCR-mediated gene disruption and other applications. Yeast 14, 115-132. doi: 10.1002/(SICI)10970061(19980130)14:2<115::AID-YEA204>3.0.CO;2-2

Brethauer, S., and Wyman, C. E. (2010). Review: continuous hydrolysis and fermentation for cellulosic ethanol production. Bioresour. Technol. 101, 4862-4874. doi: 10.1016/j.biortech.2009.11.009

Caminal, G., López-Santín, J., and Sola, C. (1985). Kinetic modeling of the enzymatic hydrolysis of pretreated cellulose. Biotechnol. Bioeng. 27, 1282-1290. doi: 10.1002/bit.260270903

Cha, Y. L., An, G. H., Yang, J., Moon, Y. H., Yu, G. D., and Ahn, J. W. (2015). Bioethanol production from Miscanthus using thermotolerant Saccharomyces cerevisiae mbc 2 isolated from the respiration-deficient mutants. Renew. Energ. 80, 259-265. doi: 10.1016/j.renene.2015.02.016

Chauve, M., Mathis, H., Huc, D., Casanave, D., Monot, F., and Ferreira, N. L. (2010). Comparative kinetic analysis of two fungal $\beta$-glucosidases. Biotechnol. Biofuels 3, 3. doi: 10.1186/1754-6834-3-3

Chomvong, K., Kordić, V., Li, X., Bauer, S., Gillespie, A. E., Ha, S. J., et al. (2014). Overcoming inefficient cellobiose fermentation by cellobiose phosphorylase in the presence of xylose. Biotechnol. Biofuels 7, 85. doi: 10.1186/1754-6834 $-7-85$

Chu, D., Zhang, J., and Bao, J. (2012). Simultaneous saccharification and ethanol fermentation of corn stover at high temperature and high solids loading by a thermotolerant strain Saccharomyces cerevisiae DQ1. Bioenerg. Res. 5, 1020-1026. doi: 10.1007/s12155-012-9219-x

den Haan, R., van Rensburg, E., Rose, S. H., Görgens, J. F., and van Zyl, W. H. (2015). Progress and challenges in the engineering of non-cellulolytic microorganisms for consolidated bioprocessing. Curr. Opin. Biotechnol. 33, 32-38. doi: 10.1016/j.copbio.2014.10.003 suggesion about protocol design, experiment operation and writing.

\section{ACKNOWLEDGMENTS}

This work was financially supported by the Ministry of Science and Technology of China ("863"Program: 2012AA02A701), and the National Natural Science Foundation of China (21390203, 31470610), Science and Technology Program of Tianjin (13RCGFSY19800).

\section{SUPPLEMENTARY MATERIAL}

The Supplementary Material for this article can be found online at: http://journal.frontiersin.org/article/10.3389/fmicb. 2016.00241

Dhaliwal, S. S., Oberoi, H. S., Sandhu, S. K., Nanda, D., Kumar, D., and Uppal, S. K. (2011). Enhanced ethanol production from sugarcane juice by galactose adaptation of a newly isolated thermotolerant strain of Pichia kudriavzevii. Bioresour. Technol. 102, 5968-5975. doi: 10.1016/j.biortech.2011.02.015

Ding, M. Z., Wang, X., Yang, Y., and Yuan, Y. J. (2012). Comparative metabolic profiling of parental and inhibitors-tolerant yeasts during lignocellulosic ethanol fermentation. Metabolomics 8, 232-243. doi: 10.1007/s11306-0110303-6

Du, J., Yuan, Y. B., Si, T., Lian, J. Z., and Zhao, H. M. (2012). Customized optimization of metabolic pathways by combinatorial transcriptional engineering. Nucleic Acids Res. 40, e142. doi: 10.1093/nar/gks549

Eriksen, D. T., Hsieh, P. C. H., Lynn, P., and Zhao, H. M. (2013). Directed evolution of a cellobiose utilization pathway in Saccharomyces cerevisiae by simultaneously engineering multiple proteins. Microb. Cell Fact. 12:61. doi: 10.1186/1475-2859-12-61

Galazka, J. M., Tian, C. G., Beeson, W. T., Martinez, B., Glass, N. L., and Cate, J. H. D. (2010). Cellodextrin transport in yeast for improved biofuel production. Science 330, 84-86. doi: 10.1126/science.1192838

Gietz, R. D., Schiestl, R. H., Willems, A. R., and Woods, R. A. (1995). Studies on the transformation of intact yeast cells by the LiAc/SS-DNA/PEG procedure. Yeast 11, 355-360. doi: 10.1002/yea.320110408

Ha, S. J., Galazka, J. M., Joong Oh, E., Kordic, V., Kim, H., Jin, Y. S., et al. (2013a). Energetic benefits and rapid cellobiose fermentation by Saccharomyces cerevisiae expressing cellobiose phosphorylase and mutant cellodextrin transporters. Metab. Eng. 15, 134-143. doi: 10.1016/j.ymben.2012.11.005

Ha, S. J., Galazka, J. M., Kim, S. R., Choi, J. H., Yang, X. M., Seo, J. H., et al. (2011). Engineered Saccharomyces cerevisiae capable of simultaneous cellobiose and xylose fermentation. Proc. Natl. Acad. Sci. U.S.A. 108, 504-509. doi: 10.1073/pnas.1010456108

Ha, S. J., Kim, H., Lin, Y. P., Jang, M. U., Galazka, J. M., Kim, T. J., et al. (2013b). Single amino acid substitutions in HXT2.4 from Scheffersomyces stipitis lead to improved cellobiose fermentation by engineered Saccharomyces cerevisiae. Appl. Environ. Microbiol. 79, 1500-1507. doi: 10.1128/AEM. 03253-12

Hahn-Hägerdal, B., Galbe, M., Gorwa-Grauslund, M. F., Liden, G., and Zacchi, G. (2006). Bio-ethanol-the fuel of tomorrow from the residues of today. Trends Biotechnol. 24, 549-556. doi: 10.1016/j.tibtech.2006.10.004

Hari Krishna, S., Reddy, T. J., and Chowdary, G. V. (2001). Simultaneous saccharification and fermentation of lignocellulosic wastes to ethanol using a thermotolerant yeast. Bioresour. Technol. 77, 193-196. doi: 10.1016/S09608524(00)00151-6

Hasunuma, T., and Kondo, A. (2012). Consolidated bioprocessing and simultaneous saccharification and fermentation of lignocellulose to ethanol with thermotolerant yeast strains. Process Biochem. 47, 1287-1294. doi: 10.1016/j.procbio.2012.05.004 
Hector, R. E., Dien, B. S., Cotta, M. A., and Qureshi, N. (2011). Engineering industrial Saccharomyces cerevisiae strains for xylose fermentation and comparison for switchgrass conversion. J. Ind. Microbiol. Biotechnol. 38, 1193-1202. doi: 10.1007/s10295-010-0896-1

Hong, K. K., Vongsangnak, W., Vemuri, G. N., and Nielsen, J. (2011). Unravelling evolutionary strategies of yeast for improving galactose utilization through integrated systems level analysis. Proc. Natl. Acad. Sci. U.S.A. 108, 12179-12184. doi: $10.1073 /$ pnas. 1103219108

Horn, S. J., Vaaje-Kolstad, G., Westereng, B., and Eijsink, V. G. (2012). Novel enzymes for the degradation of cellulose. Biotechnol. Biofuels 5, 1-13. doi: $10.1186 / 1754-6834-5-45$

Hsieh, C. W. C., Cannella, D., Jørgensen, H., Felby, C., and Thygesen, L. G. (2014). Cellulase inhibition by high concentrations of monosaccharides. J. Agric. Food Chem. 62, 3800-3805. doi: 10.1021/jf5012962

Kim, H., Lee, W. H., Galazka, J. M., Cate, J. H. D., and Jin, Y. S. (2014). Analysis of cellodextrin transporters from Neurospora crassa in Saccharomyces cerevisiae for cellobiose fermentation. Appl. Microbiol. Biotechnol. 98, 1087-1094. doi: 10.1007/s00253-013-5339-2

Kim, S. R., Park, Y. C., Jin, Y. S., and Seo, J. H. (2013). Strain engineering of Saccharomyces cerevisiae for enhanced xylose metabolism. Biotechnol. Adv. 31, 851-861. doi: 10.1016/j.biotechadv.2013.03.004

Koutinas, M., Patsalou, M., Stavrinou, S., and Vyrides, I. (2016). High temperature alcoholic fermentation of orange peel by the newly isolated thermotolerant Pichia kudriavzevii KVMP10. Lett. Appl. Microbiol. 62, 75-83. doi: $10.1111 /$ lam.12514

Kricka, W., Fitzpatrick, J., and Bond, U. (2014). Metabolic engineering of yeasts by heterologous enzyme production for degradation of cellulose and hemicellulose from biomass: a perspective. Front. Microbiol. 5:174. doi: 10.3389/fmicb.2014.00174

Kurylenko, O. O., Ruchala, J., Hryniv, O. B., Abbas, C. A., Dmytruk, K. V., and Sibirny, A. A. (2014). Metabolic engineering and classical selection of the methylotrophic thermotolerant yeast Hansenula polymorpha for improvement of high-temperature xylose alcoholic fermentation. Microb. Cell Fact. 13, 122. doi: 10.1186/s12934-014-0122-3

la Grange, D. C., den Haan, R., and van Zyl, W. H. (2010). Engineering cellulolytic ability into bioprocessing organisms. Appl. Microbiol. Biotechnol. 87, 1195-1208. doi: 10.1007/s00253-010-2660-x

Lee, W. H., Nan, H., Kim, H. J., and Jin, Y. S. (2013). Simultaneous saccharification and fermentation by engineered Saccharomyces cerevisiae without supplementing extracellular $\beta$-glucosidase. J. Biotechnol. 167, 316-322. doi: 10.1016/j.jbiotec.2013.06.016

Li, B. Z., Balan, V., Yuan, Y. J., and Dale, B. E. (2010). Process optimization to convert forage and sweet sorghum bagasse to ethanol based on ammonia fiber expansion (AFEX) pretreatment. Bioresour. Technol. 101, 1285-1292. doi: 10.1016/j.biortech.2009.09.044

Li, H. Q., Jiang, W., Jia, J. X., and Xu, J. (2014). pH pre-corrected liquid hot water pretreatment on corn stover with high hemicellulose recovery and low inhibitors formation. Bioresour. Technol. 153, 292-299. doi: 10.1016/j.biortech.2013.11.089

Li, S. J., Du, J., Sun, J., Galazka, J. M., Glass, N. L., Cate, J. H. D., et al. (2010). Overcoming glucose repression in mixed sugar fermentation by co-expressing a cellobiose transporter and a $\beta$-glucosidase in Saccharomyces cerevisiae. Mol. Biosyst. 6, 2129-2132. doi: 10.1039/c0mb00063a

Lian, J., Li, Y., HamediRad, M., and Zhao, H. (2014). Directed evolution of a cellodextrin transporter for improved biofuel production under anaerobic conditions in Saccharomyces cerevisiae. Biotechnol. Bioeng. 111, 1521-1531. doi: 10.1002/bit.25214

Lin, Y., and Tanaka, S. (2006). Ethanol fermentation from biomass resources: current state and prospects. Appl. Microbiol. Biotechnol. 69, 627-642. doi: $10.1007 /$ s00253-005-0229-x

Liu, Y., Zhang, G., Sun, H., Sun, X., Jiang, N., Rasool, A., et al. (2014). Enhanced pathway efficiency of Saccharomyces cerevisiae by introducing thermo-tolerant devices. Bioresour. Technol. 170, 38-44. doi: 10.1016/j.biortech.2014.07.063

Liu, Y., Zhou, H., Wang, L., Wang, S., and Fan, L. (2016). Improving Saccharomyces cerevisiae growth against lignocellulose-derived inhibitors as well as maximizing ethanol production by a combination proposal of $\gamma$ irradiation pretreatment with in situ detoxification. Chem. Eng. J. 287, 302-312. doi: $10.1016 /$ j.cej.2015.10.086
Liu, Z. H., Qin, L., Zhu, J. Q., Li, B. Z., and Yuan, Y. J. (2014). Simultaneous saccharification and fermentation of steam-exploded corn stover at high glucan loading and high temperature. Biotechnol. Biofuels 7, 1-16. doi: 10.1186/s13068-014-0167-x

Matsuoka, H., Hashimoto, K., Saijo, A., Takada, Y., Kondo, A., Ueda, M., et al. (2014). Cell wall structure suitable for surface display of proteins in Saccharomyces cerevisiae. Yeast 31, 67-76. doi: 10.1002/yea.2995

Narra, M., James, J. P., and Balasubramanian, V. (2015). Simultaneous saccharification and fermentation of delignified lignocellulosic biomass at high solid loadings by a newly isolated thermotolerant Kluyveromyces sp. for ethanol production. Bioresour. Technol. 179, 331-338. doi: 10.1016/j.biortech.2014.11.116

Nielsen, J., Larsson, C., van Maris, A., and Pronk, J. (2013). Metabolic engineering of yeast for production of fuels and chemicals. Curr. Opin. Biotechnol. 24, 398-404. doi: 10.1016/j.copbio.2013.03.023

Olofsson, K., Bertilsson, M., and Lidén, G. (2008). A short review on SSF-an interesting process option for ethanol production from lignocellulosic feedstocks. Biotechnol. Biofuels 1, 1-14. doi: 10.1186/1754-68 34-1-7

Park, I., Kim, I., Kang, K., Sohn, H., Rhee, I., Jin, I., et al. (2010). Cellulose ethanol production from waste newsprint by simultaneous saccharification and fermentation using Saccharomyces cerevisiae KNU5377. Process Biochem. 45, 487-492. doi: 10.1016/j.procbio.2009.11.006

Qin, L., Liu, Z. H., Jin, M., Li, B. Z., and Yuan, Y. J. (2014). High temperature aqueous ammonia pretreatment and post-washing enhance the high solids enzymatic hydrolysis of corn stover. Bioresour. Technol. 146, 504-511. doi: 10.1016/j.biortech.2013.07.099

Ruffell, J., Levie, B., Helle, S., and Duff, S. (2010). Pretreatment and enzymatic hydrolysis of recovered fibre for ethanol production. Bioresour. Technol. 101, 2267-2272. doi: 10.1016/j.biortech.2009.10.090

Sadie, C. J., Rose, S. H., den Haan, R., and van Zyl, W. H. (2011). Co-expression of a cellobiose phosphorylase and lactose permease enables intracellular cellobiose utilization by Saccharomyces cerevisiae. Appl. Microbiol. Biotechnol. 90, 1373-1380. doi: 10.1007/s00253-011-3164-z

Shao, Z. Y., Zhao, H., and Zhao, H. M. (2009). DNA assembler, an in vivo genetic method for rapid construction of biochemical pathways. Nucleic Acids Res. 37, e16. doi: 10.1093/nar/gkn991

Shi, D. J., Wang, C. L., and Wang, K. M. (2009). Genome shuffling to improve thermotolerance, ethanol tolerance and ethanol productivity of Saccharomyces cerevisiae. J. Ind. Microbiol. Biotechnol. 36, 139-147. doi: 10.1007/s10295-0080481-z

Singhania, R. R., Patel, A. K., Sukumaran, R. K., Larroche, C., and Pandey, A. (2013). Role and significance of beta-glucosidases in the hydrolysis of cellulose for bioethanol production. Bioresour. Technol. 127, 500-507. doi: 10.1016/j.biortech.2012.09.012

Tomás-Pejó, E., Oliva, J. M., Ballesteros, M., and Olsson, L. (2008). Comparison of SHF and SSF processes from steam-exploded wheat straw for ethanol production by xylose-fermenting and robust glucose-fermenting Saccharomyces cerevisiae strains. Biotechnol. Bioeng. 100, 1122-1131. doi: 10.1002/bit.21849

Treebupachatsakul, T., Nakazawa, H., Shinbo, H., Fujikawa, H., Nagaiwa, A., Ochiai, N., et al. (2016). Heterologously expressed Aspergillus aculeatus $\beta$-glucosidase in Saccharomyces cerevisiae is a cost-effective alternative to commercial supplementation of $\beta$-glucosidase in industrial ethanol production using Trichoderma reesei cellulases. J. Biosci. Bioeng. 121, 27-35. doi: 10.1016/j.jbiosc.2015.05.002

Wang, X., Bai, X., Chen, D. F., Chen, F. Z., Li, B. Z., and Yuan, Y. J. (2015). Increasing proline and myo-inositol improves tolerance of Saccharomyces cerevisiae to the mixture of multiple lignocellulose-derived inhibitors. Biotechnol. Biofuels 8, 142. doi: 10.1186/s13068-015-0329-5

Weber, C., Farwick, A., Benisch, F., Brat, D., Dietz, H., Subtil, T., et al. (2010). Trends and challenges in the microbial production of lignocellulosic bioalcohol fuels. Appl. Microbiol. Biotechnol. 87, 1303-1315. doi: 10.1007/s00253-0102707-z

Wu, W. H., Hung, W. C., Lo, K. Y., Chen, Y. H., Wan, H. P., and Cheng, K. C. (2016). Bioethanol production from taro waste using thermo-tolerant yeast Kluyveromyces marxianus K21. Bioresour. Technol. 201, 27-32. doi: 10.1016/j.biortech.2015.11.015 
Yuan, Y. B., and Zhao, H. M. (2013). Directed evolution of a highly efficient cellobiose utilizing pathway in an industrial Saccharomyces cerevisiae strain. Biotechnol. Bioeng. 110, 2875-2881. doi: 10.1002/bit.24946

Zha, J., Hu, M. L., Shen, M. H., Li, B. Z., Wang, J. Y., and Yuan, Y. J. (2012). Balance of XYL1 and XYL2 expression in different yeast chassis for improved xylose fermentation. Front. Microbiol. 3:355. doi: 10.3389/fmicb.2012.00355

Zha, J., Li, B. Z., Shen, M. H., Hu, M. L., Song, H., and Yuan, Y. J. (2013). Optimization of CDT-1 and XYL1 expression for balanced co-production of ethanol and xylitol from cellobiose and xylose by engineered Saccharomyces cerevisiae. PLoS ONE 8:e68317. doi: 10.1371/journal.pone.0068317

Zha, J., Shen, M. H., Hu, M. L., Song, H., and Yuan, Y. J. (2014). Enhanced expression of genes involved in initial xylose metabolism and the oxidative pentose phosphate pathway in the improved xylose-utilizing Saccharomyces cerevisiae through evolutionary engineering. J. Ind. Microbiol. Biotechnol. 41, 27-39. doi: 10.1007/s10295-013-1350-y

Zhang, M., Su, R., Qi, W., and He, Z. (2010). Enhanced enzymatic hydrolysis of lignocellulose by optimizing enzyme complexes. Appl. Biochem. Biotechnol. 160, 1407-1414. doi: 10.1007/s12010-009-8602-3

Zhang, Z., Donaldson, A. A., and Ma, X. (2012). Advancements and future directions in enzyme technology for biomass conversion. Biotechnol. Adv. 30, 913-919. doi: 10.1016/j.biotechadv.2012.01.020

Zhao, J., and Xia, L. (2009). Simultaneous saccharification and fermentation of alkaline-pretreated corn stover to ethanol using a recombinant yeast strain. Fuel Process Technol. 90, 1193-1197. doi: 10.1016/j.fuproc.2009.05.018
Zhong, C., Cao, Y. X., Li, B. Z., and Yuan, Y. J. (2010). Biofuels in China: past, present and future. Biofuels Bioprod. Bioref. 4, 326-342. doi: 10.1002/ bbb. 207

Zhu, J. Q., Qin, L., Li, B. Z., and Yuan, Y. J. (2014). Simultaneous saccharification and co-fermentation of aqueous ammonia pretreated corn stover with an engineered Saccharomyces cerevisiae SyBE005. Bioresour. Technol. 169, 9-18. doi: 10.1016/j.biortech.2014. 06.085

Zhu, J. Q., Qin, L., Li, W. C., Zhang, J., Bao, J., Huang, Y. D., et al. (2015). Simultaneous saccharification and co-fermentation of dry diluted acid pretreated corn stover at high dry matter loading: overcoming the inhibitors by non-tolerant yeast. Bioresour. Technol. 198, 39-46. doi: 10.1016/j.biortech.2015.08.140

Conflict of Interest Statement: The authors declare that the research was conducted in the absence of any commercial or financial relationships that could be construed as a potential conflict of interest.

Copyright (c) $2016 \mathrm{Hu}$, Zha, He, Lv, Shen, Zhong, Li and Yuan. This is an open-access article distributed under the terms of the Creative Commons Attribution License (CC $B Y)$. The use, distribution or reproduction in other forums is permitted, provided the original author(s) or licensor are credited and that the original publication in this journal is cited, in accordance with accepted academic practice. No use, distribution or reproduction is permitted which does not comply with these terms. 